\title{
Os gêneros Besleria, Codonanthe, Gloxinia, Napeanthus, Nematanthus e Seemannia (Gesneriaceae) no estado do Paraná
}

The genera Besleria, Codonanthe, Gloxinia, Napeanthus, Nematanthus and Seemannia (Gesneriaceae) in the state of Paraná

\author{
Lucas Katsumi Rocha Hinoshita ${ }^{1,4}$, Andrea Onofre de Araújo $^{2}$ \& Renato Goldenberg ${ }^{3}$
}

\begin{abstract}
Resumo
A família Gesneriaceae apresenta sete gêneros e 39 espécies no Paraná: Besleria (1 sp), Codonanthe (3), Gloxinia (1), Napeanthus (2), Nematanthus (6), Seemannia (1) e Sinningia (25). Neste trabalho apresentamos o tratamento taxonômico para os seis primeiros gêneros, ou seja, para toda família exceto Sinningia (em preparação), trazendo uma chave de identificação para as espécies, descrições, dados sobre distribuição e fenologia e ilustrações para cada espécie registrada no estado.
\end{abstract}

Palavras-chave: Columneinae, Gesnerioideae, Gloxiniinae, Mata-Atlântica, Napeantheae.

\begin{abstract}
The family Gesneriaceae has seven genera and 39 species in the state of Paraná: Besleria (1 sp), Codonanthe (3), Gloxinia (1), Napeanthus (2), Nematanthus (6), Seemannia (1) and Sinningia (25). In this work we present a taxonomic treatment for the first six genera, i.e. for the whole family except for Sinningia, whose monograph is in preparation. We provide an identification key for species, descriptions, data on distribution and phenology and illustrations for each species recorded to Paraná.

Key words: Columneinae, Gesnerioideae, Gloxiniinae, Atlantic Rainforest, Napeantheae.
\end{abstract}

\section{Introdução}

A família Gesneriaceae DC. compreende mais de 3500 espécies em cerca de 150 gêneros (Burtt \& Wiehler 1995; Chautems \& Matsuoka 2003; Weber 2004b; Weber et al. 2013), de distribuição principalmente tropical, com poucas espécies em regiões subtropicais (Ásia e Europa, Weber 2004b). Gesneriaceae tem maior diversidade no leste da África e noroeste da América do Sul (Weber 2004b), além de um centro secundário de diversidade reconhecido no sudeste brasileiro (Chautems 1991).

Muitas espécies de Gesneriaceae tem potencial ornamental e algumas espécies nativas são muito usadas para essa finalidade, principalmente dos gêneros Codonanthe, Gloxinia, Nematanthus, Seemannia e Sinningia. Algumas espécies exóticas são também cultivadas principalmente devido à sua beleza, facilidade de cultivo e fácil adaptação ao interior das residências. As mais comuns são a violeta-africana (Saintpaulia ionantha H.Wendl.) e diversas espécies dos gêneros Achimenes Pers., Aeschinanthus Endl., Columnea L. e Streptocarpus Lindl. (Lorenzi \& Souza 2008).

A família é dividida em três subfamílias: Didymocarpoideae, Gesnerioideae e Sanangoideae (Weber et al. 2013). Didymocarpoideae apresenta uma redução de um dos cotilédones e endosperma ausente, enquanto que Gesnerioideae apresenta cotilédones com desenvolvimento normal e endosperma desenvolvido. Sanangoideae é uma subfamília monogenérica, e a inclusão de Sanango G.S. Bunting \& Duke em Gesneriaceae foi recentemente proposta (Perret et al. 2013; Weber 2004a, 2004b; Weber et al. 2013). A única subfamília ocorrente no Brasil é Gesnerioideae, que abriga 5 tribos e é principalmente neotropical

\footnotetext{
${ }^{1}$ Universidade Federal do Paraná, Depto. Botânica, Av. Cel. Francisco H. Santos, s.n., Jardim das Américas, 81531-970, Curitiba, PR, Brasil.

${ }^{2}$ Universidade Federal do ABC, Centro de Ciências Naturais e Humanas, R. Sta. Adélia 166, 09210-580, Bangu, Santo André, SP, Brasil.

${ }^{3}$ Universidade Federal do Paraná, Depto. Botânica, Av. Cel. Francisco H. Santos, s.n., Jardim das Américas, 81531-970, Curitiba, PR, Brasil.

${ }^{4}$ Autor para correspondência: katsumilucas@gmail.com
} 
(Smith 1996; Smith et al. 1997; Wiehler 1983). No Brasil até agora ocorrem 28 gêneros e 220 espécies, das quais 148 são endêmicas (Chautems 1991; Chautems \& Matsuoka 2003; BFG 2015). No Paraná, em uma listagem preliminar, foram registrados 7 gêneros e 39 espécies (Hinoshita \& Goldenberg 2014).

$\mathrm{O}$ estado é o quarto maior em diversidade de Gesneriaceae no Brasil. Rio de Janeiro (56), São Paulo (55) e Amazonas (45) detém o maior número de espécies (BFG 2015). O objetivo deste trabalho é realizar o levantamento das espécies de Gesneriaceae registradas no estado do Paraná, com descrições, mapas de distribuição, chaves de identificação e ilustrações. Aqui apresentamos os gêneros com menor número de espécies no estado, a saber Besleria L., Gloxinia L'Hér., Napeanthus Gardner, Nematanthus Schrad. e Seemannia Regel. A monografia sobre Sinningia Nees está em preparação, e por ser o maior gênero de Gesneriaceae no Paraná será publicado em um artigo separado.

\section{Materiais e Métodos}

O estado do Paraná está localizado na região sul brasileira, e faz fronteira com os estados de São Paulo ao norte e Santa Catarina ao sul, e com Paraguai e Argentina a oeste. Ocupando cerca de $2,5 \%$ do território nacional, o estado é o $13^{\circ} \mathrm{em}$ extensão, com $199.315 \mathrm{~km}^{2}$. O clima predominante no estado é subtropical, tendo, segundo o sistema de classificação climática de Köppen, dois tipos de climas principais: Subtropical úmido, Cfa, e temperado oceânico, Cfb (Maack 1978). Cfa é encontrado no litoral e na região nordeste do estado, sendo um clima subtropical com verões quentes, sem estação seca definida. Já Cfb é encontrado nas porções central e oeste, sendo um clima subtropical, com verões amenos e geadas frequentes no inverno, também sem estação seca definida (IAPAR 1978).

O estado apresenta cinco diferentes unidades fitogeográficas distintas: Floresta Ombrófila Densa, Floresta Ombrófila Mista, Floresta Estacional Semidecidual, Savana (Cerrado) e Estepes ou Campos. (Labiak 2014; Roderjan et al.2002; Veloso et al.1992). O Paraná abriga 7.367 espécies de plantas vasculares e, dessas, 5.590 são angiospermas (Kaehler et al. 2014).

Este trabalho foi baseado na análise de cerca de 200 exsicatas dos herbários EFC, JOI, MBM, R, RB, MBM, UPCB, SP (acrônimos conforme Thiers, continuamente atualizado). As análises morfológicas foram feitas com materiais não hidratados, no caso de estruturas vegetativas, ou hidratados, no caso de estruturas reprodutivas, com auxílio de microscópio estereoscópico. Medições foram tomadas com paquímetro. As ilustrações foram feitas pelo primeiro autor com auxílio de câmara clara. As características utilizadas para a descrição das espécies foram baseadas em Chautems \& Matsuoka (2003), Chautems et al. (2010), Weber (2004) e Araujo et al. (2005). A distribuição geográfica das espécies no Brasil foi obtida a partir de BFG (2015). A distribuição no Paraná e informações fenológicas foram obtidas a partir da informação contida nas etiquetas das exsicatas. A descrição da família foi baseada em Weber $(2004,2013)$ e Chautems \& Matsuoka (2003) e dos gêneros Besleria e Napeanthus em Chautems \& Matsuoka (2003); de Codonanthe em Chautems \& Perret (2013); de Gloxinia e Seemannia em Araujo (2007) e de Nematanthus em Chautems (1988, 2005). As descrições das espécies foram obtidas exclusivamente a partir da análise de plantas coletadas no Paraná. Para espécies com muitas coletas, foi listada apenas uma coleta por município e, neste caso, as amostras foram apresentadas como "Material Selecionado"; todos os espécimes examinados estão listados ao final do trabalho, em uma lista de coletores. Para Besleria selloana Klotzsch \& Hanst., Codonanthe cordifolia Chautems, C. devosiana Lem., Gloxinia perennis (L.) Fritsch, Napeanthus primulifolius (Raddi) Sandwith, N. reitzii (L.B. Sm.) B.L. Burtt ex Leewenb., Nematanthus maculatus (Fritsch) Wiehler e Seemannia sylvatica (Kunth.) Baill não havia material coletado no estado em quantidade suficiente; neste caso, foram também utilizadas amostras provenientes de estados vizinhos, e estas foram listadas como "Material Adicional".

\section{Resultados e Discussão}

Gesneriaceae está representada no Paraná por sete gêneros e 39 espécies. Dentre os gêneros aqui estudados, o mais diverso é Nematanthus (6), seguido por Codonanthe (3), Napeanthus (2), Besleria (1), Gloxinia (1) e Seemannia (1). Esses seis gêneros são encontrados nas Florestas Ombrófilas Densa e Mista, onde Nematanthus e Codonanthe são abundantes e importantes na composição da flora epífita. Napeanthus e Besleria são encontrados em florestas muito úmidas do litoral e são raros. Gloxinia e Seemannia são gêneros exóticos do Paraná e as plantas encontradas no estado são provavelmente provenientes de cultivo. 
Gesneriaceae DC., Essai Prop. Méd. Pl. 2: 192. 1829.

Ervas, subarbustos, arbustos, trepadeiras ou pequenas árvores, perenes ou raramente anuais. Terrestres, rupícolas ou epífitas. Sistema subterrâneo com raízes fibrosas, rizomas ou caule tuberoso. Caule herbáceo ou lenhoso, cilíndrico, quadrado ou ausente, ereto ou pendente. Folhas opostas, verticiladas ou em roseta, raro alternas, sem estípulas. Flores vistosas, solitárias ou dispostas em inflorescências bracteosas ou foliosas, do tipo cimosas, tirsos, ou dicásios; sépalas livres ou conadas em extensão variável; pétalas conadas formando um tubo com 5 lobos iguais ou bilabiados estames 4 ou 2, raramente 5 , estaminódios às vezes presentes, 1 ou 3 , base dos filetes fundidos ao tubo da corola, anteras coerentes aos pares ou em 4, didínamos; nectário adpresso ao ovário ou livre, anular ou dividido em várias glândulas ou ausente; ovário bicarpelar, unilocular, placentação parietal, súpero a ínfero, estilete bem desenvolvido, estigma bífido, claviforme ou estomatomórfico, óvulos numerosos. Fruto deiscente seco, carnoso ou indeiscente. Sementes numerosas, elípticas ou poligonais, testa estriada.

\section{Chave de identificação dos gêneros Besleria, Codonanthe, Gloxinia, Napeanthus, Nematanthus e Seemannia (Gesneriaceae) no Paraná, Brasil}

1. Plantas com sistema caulinar subterrâneo (caule tuberoso ou rizomas); ovário semi-ínfero a ínfero ... 2

2. Inflorescência bracteosa; corola campanulada, lilás a rosada, fauce glabra; estigma estomatomórfico 3.1. Gloxinia perennis

2'. Inflorescência foliosa; corola tubular, vermelha externamente, fauce com tricomas glandulares; estigma clavado 6.1. Seemannia sylvatica

1’. Plantas sem sistema subterrâneo desenvolvido; ovário súpero ......................................................... 3

3. Plantas terrestres; sementes com funículo delgado ................................................................. 4

4. Folhas opostas; flores com corola amarela na base e alva no ápice; baga

4'. Folhas em roseta; flores com corola azulada; cápsula 1.1. Besleria selloana

5. Sépalas elípticas a lanceoladas, membranáceas 4.1. Napeanthus primulifolius

5'. Sépalas triangulares, papiráceas 4.2. Napeanthus reitzii

3'. Plantas epífitas ou rupícolas; sementes com funículo carnoso

6. Folhas sem hipoderme desenvolvida; flores com corola alva, rosada ou pontuada de castanho, anteras poricidas, conectivo desenvolvido; fruto do tipo baga

7. Planta pubescente 2.2. Codonanthe devosiana

7'. Planta glabra a glabrescente

8. Folhas elípticas, ovadas ou lanceoladas; sépalas lanceoladas a triangulares .

2.3. Codonanthe gracilis

8'. Folhas cordiformes; sépalas lineares a estreito lanceoladas

2.1. Codonanthe cordifolia

6'. Folhas com hipoderme desenvolvida em um tecido aquífero suculento; flores com corola alaranjada, amarela ou vermelha, anteras rimosas, conectivo pouco desenvolvido; fruto do tipo cápsula carnosa

9. Flores ressupinadas

10. Plantas com mácula vinácea na face adaxial das folhas

5.4. Nematanthus maculatus

10’. Plantas sem mácula vinácea na face adaxial das folhas

11. Plantas vilosas; corola avermelhada ou alaranjada

11'. Plantas pubescentes a glabrescentes; corola amarela ou amarela com estrias castanhas

12. Cálice vináceo a atropúrpureo; corola amarela sem estrias

12'. Cálice verde a rosado; corola amarela com estrias castanhas a vináceas 5.5. Nematanthus tessmannii 
9'. Flores não ressupinadas

13. Sépalas lineares; corola pubescente

5.6. Nematanthus wettsteinii

13'. Sépalas elípticas a ovadas; corola glabra ou pilosa próximo aos lobos

5.1. Nematanthus australis

1. Besleria Plum. ex L., Sp. Pl. 2: 619. 1753.

Arbustos, perenes, terrestres, sem sistema caulinar subterrâneo. Caule ereto, sem raízes adventícias. Folhas opostas, iso ou anisófilas, membranáceas a papiráceas. Inflorescências axilares, cimeira fasciculada raramente reduzida a uma flor; brácteas reduzidas; bractéolas muitas vezes ausentes; corola pouco zigomórfica; estames 4 , inclusos, estaminódio presente, conectivo pouco desenvolvido, anteras rimosas; nectário único, anelar a anelar lobado; ovário súpero, estigma bilobado. Fruto do tipo baga, sementes com funículo delgado.

Gênero com cerca de 200 espécies, distribuídas principalmente entre a Bolívia e a América Central, com centros de diversidade no Equador e Colômbia, e algumas espécies endêmicas da Mata Atlântica ou do Caribe (Ferreira et al. 2016; Lopes et al. 2008; Wiehler 1983). No Brasil ocorrem 19 espécies (BFG 2015) e somente Besleria selloana no Paraná.

1.1. Besleria selloana Klotzsch \& Hanst. in Mart., Fl. bras. 8(1): 398. $1864 . \quad$ Figs. 1a-c; 2a

Arbustos 0,4-1 m alt. Folhas com pecíolo 1,5-5,3 cm compr., verde, pubescente; lâmina 9,6-25,9 × 4,2-8,6 cm, elíptica a ovada, cartácea, verde escura em ambas as faces, pilosa em ambas as faces e sobre as nervuras, ápice agudo, base aguda a obtusa, margem serrilhada, nervuras secundárias 9-15. Cimeiras reduzidas a uma ou até 12 flores, pedúnculo 2,1-4,6 cm compr.; flores com pedicelo 1,8-3,3 cm compr., cilíndrico, verde a verdeavermelhado próximo à base, pubérulo; bractéolas 2-4 × 1-2 mm, elípticas; sépalas 8-13 × 3-4 mm, unidas próximo à base, elípticas, adpressas ao tubo da corola, margem inteira, papiráceas, amareladas, pubescentes; corola 1,6-1,9 ×0,5-0,8 cm, tubulosa, levemente gibosa próximo à abertura, amarela na base e alva no ápice, pubescente, lobos 2-6× 2-5 mm, orbiculares, eretos, desiguais, três lobos inferiores mais desenvolvidos do que os superiores; estames 6-7 mm compr., filetes alvos a amarelos; ovário 1,7-5 × 3-4,2 mm, elíptico, pubescente, branco-amarelado, estilete $8,4-10,4 \mathrm{~mm}$ compr., amarelado, pubescente, estigma bilobado. Baga $0,7-1,8 \times 0,5-1 \mathrm{~cm}$, ovóide, verde quando imatura, e amarela quando madura.
Material analisado: Antonina, 31.X.1973, fl., G. Hatschbach 32987 (BHCB, MBM). Guaraqueçaba, 19.XI.1983, fl. e fr., R. Lima 178 (UPCB).

Material adicional: BRASIL. SÃO PAULO: Cubatão, 22.IX.1988, fl., O.T. Aguiar 263 (MBM, SPSF). Juquitiba, 12.IX.1998, fl., G. Hashimoto (MBM, 21780). Santos, 22.X.1966, fl., J. Lindeman 3201 (MBM). Santo André, 18.X.1983, fl., M. Kirizawa 1088 (SP); 8.V.2008, fr., A. Santos 38 (SP). São Bernardo do Campo, 28.XI.1994, fl. e fr., E.L.C. Marzola 155 (SP); 4.XI.1992, fl. e fr., M. Sugiyama 1074 (SP).

Espécie endêmica do Brasil, Besleria selloana é encontrada nos estados de São Paulo e Paraná (BFG 2015). Ocorre no Paraná em Floresta Ombrófila Densa, restrita a regiões litorâneas, em locais sombreados e úmidos. Coletada com flores em outubro e novembro e com frutos em novembro. São pequenos arbustos de até um metro com flores de cálice amarelo e corola alva. É diferenciada de B. umbrosa Mart. pelas inflorescências geralmente com mais de cinco flores e pelo ápice das sépalas, que é agudo nessa espécie.

2. Codonanthe Hanst., Linnaea 26: 209. 1854.

Ervas ou subarbustos perenes epifíticos, sem sistema caulinar subterrâneo. Caule pendente ou rastejante, com raízes adventícias. Folhas opostas, iso ou anisófilas, carnosas, sem hipoderme desenvolvida, nervuras não visíveis. Inflorescências axilares, cimosas reduzidas a 1-2 flores; brácteas ausentes; bráctéolas presentes aos pares na base do pedicelo; corola zigomórfica, campanulada, gibosa, oblíqua em relação ao eixo do cálice; estames 4, inclusos, estaminódio ausente, conectivo desenvolvido, anteras poricidas; nectário único, dorsal, bilobado; ovário súpero, estigma estomatomórfico. Fruto do tipo baga; sementes com funículo carnoso.

Gênero endêmico do Brasil, com oito espécies distribuídas principalmente no sudeste brasileiro (Chautems \& Perret 2013; BFG 2015) e três delas ocorrentes no Paraná.

2.1. Codonanthe cordifolia Chautems, Candollea 52(1): 159. 1997.

Fig. 3a

Ervas ou subarbustos, $25-30 \mathrm{~cm}$ compr., caule cilíndrico, verde, glabro a glabrescente. Folhas pouco anisófilas; pecíolo 1,4-3 mm 


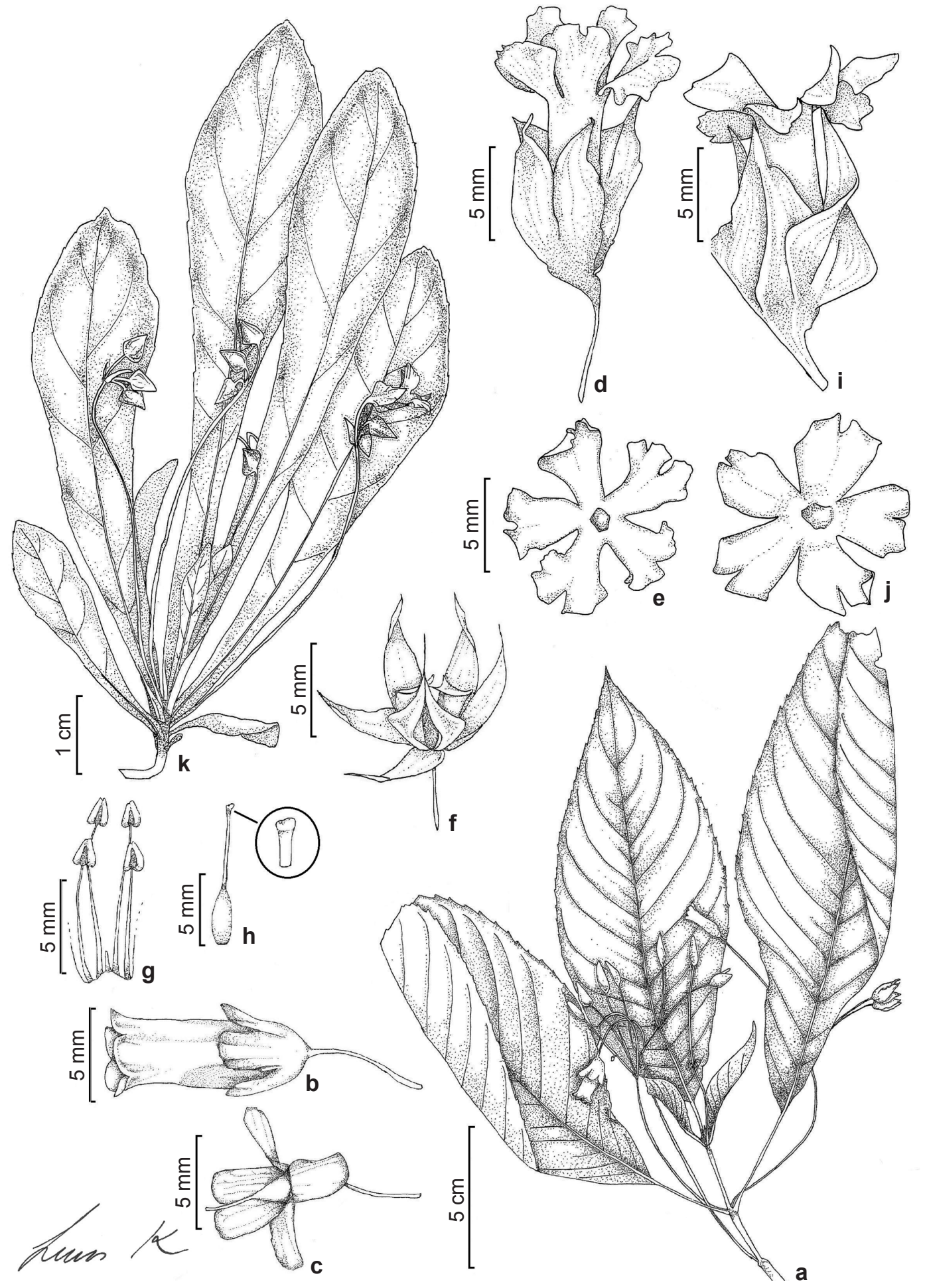

Figura 1 - a-c. Besleria selloana - a. hábito; b. vista lateral das flores; c. flor com corola removida, mostrando ovário e nectário. d-h. Napeanthus primulifolius - d-e. vista lateral e superior das flores; f. fruto; g. estames e estaminódio; h. gineceu. i-k. N. reitzii -i-j. vista lateral e superior das flores; k. hábito. (a-c. Lima 178; d-h. Hatschbach 26267; i-k. Hatschbach 12037).

Figure 1 -a-c. Besleria selloana - a. habit; b. side view of the flowers; c. flower without the corolla, showing the ovary and nectary. d-h. Napeanthus primulifolius - d-e. side and top views of the flowers; f. fruit; g. stamens and staminode; h. pistil. i-k. N. reitzii-i-j. side and top views of the flowers; k. habit. (a-c. Lima 178; d-h. Hatschbach 26267; i-k. Hatschbach 12037). 

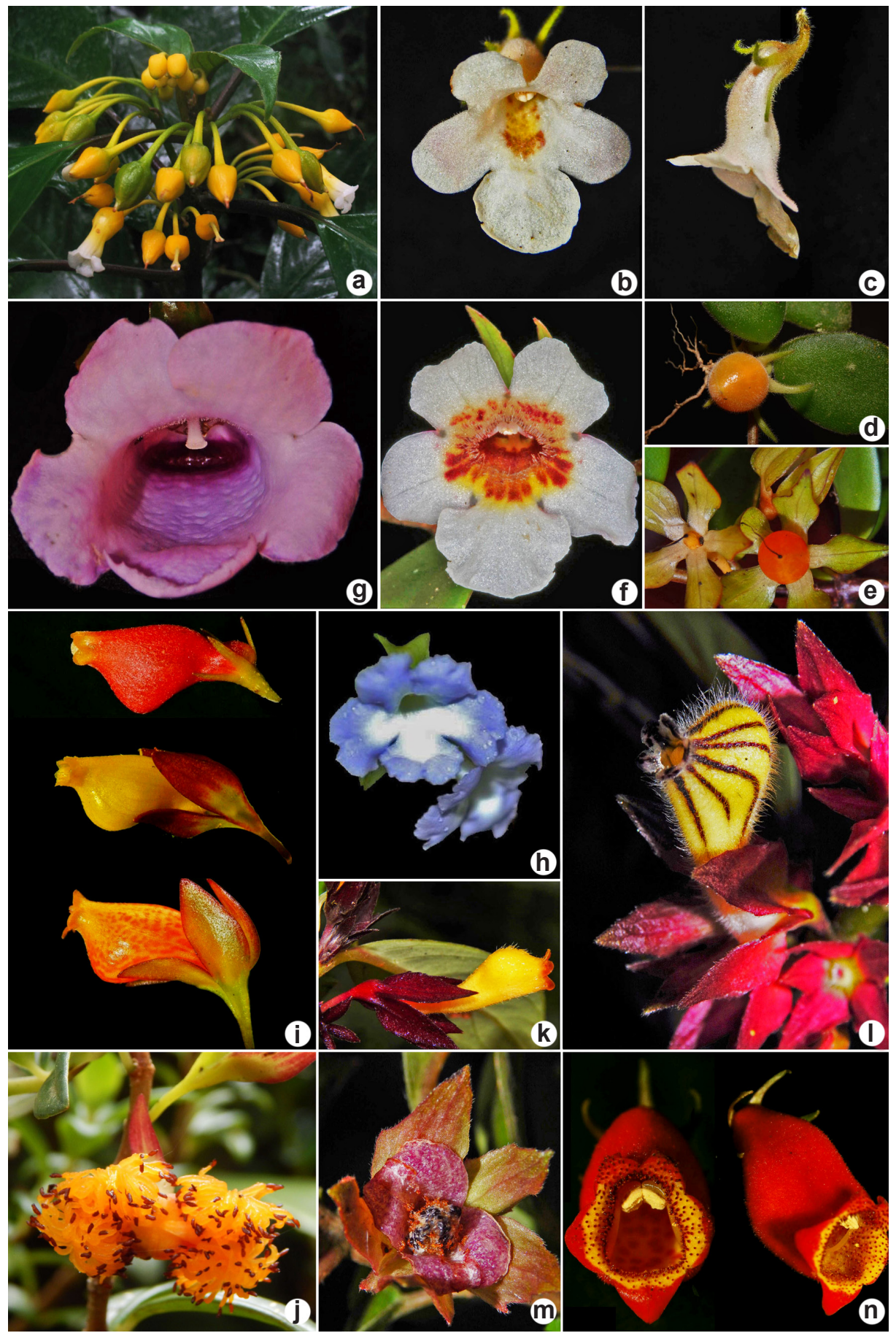

Figura 2 - a. Besleria selloana. b-d. Codonanthe devosiana - b-c. vista frontal e lateral da flor; d. fruto. e-f. Codonanthe gracilis - e. fruto; f. vista frontal da flor. g. Gloxinia perennis. h. Napeanthus reitzii. i. Nematanthus wettsteinnii, Nematanthus australis (forma amarela) e Nematanthus australis (forma estriada). j. Nematanthus australis - fruto. k. Nematanthus jolyanus. 1-m. Nematanthus tessmannii - 1 . vista lateral da flor; $\mathrm{m}$. fruto. n. Seemannia sylvatica - vista frontal e lateral da flor. (Foto: a. Gabriel Emiliano Ferreira; h. Paulo Schwirkowski; as demais dos autores).

Figure 2 - a. Besleria selloana. b-d. Codonanthe devosiana - b-c. front and side view of the flower. d. fruit. e-f. Codonanthe gracilis - e. fruit; f. front view of the flower. g. Gloxinia perennis. h. Napeanthus reitzii. i. Nematanthus wettsteinnii, Nematanthus australis (yellow form) e Nematanthus australis (striated form). j. Nematanthus australis - fruto. k. Nematanthusjolyanus. 1-m. Nematanthus tessmannii-1. side view of the flower, $\mathrm{m}$. fruit. n. Seemannia sylvatica - front and side view of the flower. (Photo: a. Gabriel Emiliano Ferreira; h. Paulo Schwirkowski; the others from the authors). 
compr., cilíndrico, verde, glabro; lâmina 2,3-4,2 $\times 1,5-2,8 \mathrm{~cm}$, cordiforme, crassa, verde em ambas as faces, um pouco discolor, glabra, ápice agudo, base cordada, margem inteira. Flores com pedicelo 3,5-4,8 $\mathrm{mm}$ compr., cilíndrico, verde a verde avermelhado próximo à base, glabro; sépalas 6,5-8,5 × 1,3-2,1 mm, lineares a estreitolanceoladas, patentes, lobos do cálice 5-6,5 mm compr., margem inteira, crassos, verde a avermelhados no ápice, glabros; corola 9,8-14,6 $\times$ 3,3-4,4 mm, tubuloso-campanulada, inflada e levemente gibosa próximo a abertura, externamente muito pontuada de castanho, fauce alvo-amarelada com muitas pontuações castanhas, glabra, com tricomas glandulares no ventre próximo à abertura, lobos 2,4-2,8 × 2,1-3,5 mm, eretos, desiguais, brancos; estames 7,2-10 mm compr., filetes alvos a amarelos; ovário 2,6-2,8 × 1,8-2,1 mm, ovóide, glabro, amarelado, estilete 2,2-3,8 mm compr., amarelado, pubescente, estigma bilabiado. Baga 6,2-8,8 × 5,7-6,7 mm, ovóide, glabra, alaranjada. Material analisado: Guaratuba, 23.VII.2014, fl., J.T. Motta 4400 (MBM).

Material adicional: BRASIL. ESPÍRITO SANTO: Castelo, 20.I.2009, fl. e fr., R. Goldenberg 1269 (MBM, UPCB). SANTA CATARINA: Ibirama, 17.VII.1956, fl., R. Reitz 3398 (R). Joinville, 6.VII.2006, fl. e fr., $W$. Mancinelli 638 (MBM); 31.VII.2005, fl., F.C.S. Vieira 1175 (MBM, JOI). SÃO PAULO: Bananal, 24.XI.1981, fl., G. Martinelli 7776 (RB, Parátipo). Serra do Mar, 22.VIII.1976, fl., P.H. Davis 59909 (MBM, UEC). RIO DE JANEIRO: Macaé, 23.X.1985, fl., M. Leitmann 75 (RB). Petrópolis, 6.X.1983, fl., G. Martinelli 9600 (RB). Teresópolis, 2.II.1983, fl. e fr., G. Martinelli 9066 (RB, Parátipo).

Espécie endêmica do Brasil, ocorre nos estados de Santa Catarina, São Paulo, Rio de Janeiro, Minas Gerais, Espírito Santo e Bahia (BFG 2015). No Paraná ocorre em Floresta Ombrófila Densa. Esta espécie é abundante nos estados vizinhos e rara no Paraná, sendo encontrada somente em Guaratuba. Coletada com flores em julho e agosto e frutos em janeiro e julho. A planta pode ser distinguida de outras espécies de Codonanthe pelas folhas cordiformes e pelas flores muito manchadas de castanho.

2.2. Codonanthe devosiana Lem., L'Ill. Hort. 2: t. 56. 1855.

Figs. 2b-d; 3b-f

Ervas ou subarbustos, 15-55 cm compr., caule cilíndrico, verde, pubescente. Folhas pouco anisófilas; pecíolo 1,3-4,4 mm compr., cilíndrico, verde, pubescente; lâmina 0,9-2,1 × 0,7-1,4 $\mathrm{cm}$, elíptica, ovada a orbicular, crassa, verde em ambas as faces, discolor, pubescente em ambas as faces, ápice agudo a obtuso, base obtusa, margem inteira, verde ou avermelhada. Flores com pedicelo 2,8-5,9 mm compr., cilíndrico, verde a verde avermelhado próximo à base, pubescente; sépalas 2,3-6,6 × 0,5-1,5 mm, lineares, eretas a patentes, lobos do cálice 1,3-3,5 mm compr., margem inteira, crassos, verdes a avermelhados no ápice, pubescentes; corola 9-18,5 × 3,6-8,3 $\mathrm{mm}$, tubuloso campanulada, inflada e gibosa próximo à abertura, branca ou rosada, com pontuações castanhas na garganta, internamente, próximo ao ápice, pubescente mas com tricomas glandulares próximos à abertura, lobos 1,6-6,3 $\times$ 2,4-5,2 mm, patentes, desiguais, brancos; estames 6-6,5 mm compr., filetes alvos ou brancoamarelados; ovário 1,3-2,6 × 1,1-1,7 mm, ovóide, pubescente, amarelado, estilete 2,4-4 mm compr., amarelado, pubescente, estigma estomatomórfico. Baga 4,9-7,3 × 3,4-4,7 mm, ovóide, pubescente, alaranjada.

Material selecionado: Antonina, 5.VIII.2001, fl., J. Carneiro 1130 (MBM). Campina Grande do Sul, 1.IV.1962, fl., G. Hatschbach 9090 (MBM). Guaratuba, 26.VII.1974, fl. P.L. Krieger 13357 (CESJ, MBM). Guaraqueçaba, Ilha do Superagui, 13.V.1989, fl., J.T. Motta 1687 (MBM). Matinhos, 7.IX.1999, fl. e fr., $S$. Dala Rosa 34 (MBM, UPCB). Morretes, 4.V.2000, fl., A.C. Cervi. 7040 (UPCB). Paranaguá, 27.VII.1966, fl., $H$. Moreira-Filho (UPCB 9771); Ilha do Mel, 1.VIII.1986, fl., W.S. Souza (MBM 112894). Pontal do Sul, IV.2015, fl. e fr., E.C. Smidt 1076 (UPCB). Serra do Mar, 1.IV.1982, fl., A.C. Cervi 1973 (UPCB).

Material adicional: BRASIL. SANTA CATARINA: São Bento do Sul, 16.VI.2008, fl. e fr., F.S. Meyer 765 (JOI, UPCB). Paulo Lopes, 10.VI.2010, fl., M. Verdi 4923 (JOI).

Espécie endêmica do Brasil, encontrada nos estados do Rio Grande do Sul, Santa Catarina, Paraná, São Paulo, Rio de Janeiro, Minas Gerais e Espírito Santo (BFG 2015). No Paraná ocorre em Floresta Ombrófila Densa e Mista, mas é mais abundante no estrato epifítico das florestas litorâneas, onde frequentemente está associada à C. gracilis. Coletada com flores de abril a janeiro e com frutos de junho a dezembro. Espécie semelhante a C. carnosa (Gardner) Hanst., da qual difere pelo cálice e corola menores que $1,5 \mathrm{~cm}$.

2.3. Codonanthe gracilis Hanst., Linnaea 26: 209. 1854. Figs. 2e,f; 3g,h

Subarbustos, 15-45 cm compr., caule cilíndrico, verde ou marrom, glabro a glabrescente. Folhas pouco anisófilas; pecíolo $0,3-4,5 \mathrm{~cm}$ 
compr., cilíndrico, verde, glabro, glabrescente ou pubescente; lâmina 1,8-7,5 ×0,9-1,9 cm, elíptica, ovada ou lanceolada, crassa, verde em ambas as faces, um pouco discolor, glabra a glabrescente em ambas as faces, ápice agudo a acuminado, base aguda a obtusa, margem inteira. Flores com pedicelo 0,6-1,2 cm compr., cilíndrico, verde a verde avermelhado, glabrescente; sépalas $0,8-1,2$ $\times 0,3-0,7 \mathrm{~cm}$, pouco unidas próximo à base, lanceoladas a triangulares, eretas a patentes, lobos do cálice 0,7-1,2 cm compr., margem inteira, crassos, verdes, glabros a glabrescentes; corola $0,9-2,9 \times 0,5-1,1 \mathrm{~cm}$, tubulosa, campanulada, inflada e gibosa próximo à abertura, brancas com pontuações castanhas na base e no ápice externamente, e pontuações no tubo internamente, pubescentes com tricomas glandulares próximos à abertura; lobos $0,3-0,7 \times 0,3-1,1 \mathrm{~cm}$, patentes, desiguais, brancos; estames $0,4-1,3 \mathrm{~cm}$ compr., filetes alvos a branco-amarelados; ovário súpero $0,3-0,4 \times 0,2-0,3 \mathrm{~cm}$, ovóide, glabrescente, verde, estilete 7-9 mm compr., amarelado, pubescente, estigma estomatomórfico. Baga 0,9-1,5 × 0,5-1,24 $\mathrm{cm}$, ovóide, pubescente, alaranjada.

Material selecionado: Antonina, 11.X.1964, fl., Y.S. Kuniyoshi 306 (MBM). Cerro Azul, 5.X.1977, fl., G. Hatschbach 40344 (MBM). Guaraqueçaba, 19.VII.1998, fl., A.L.S. Gatti 75 (UPCB). Guaratuba, 1.XI.1996, fl., J.M. Silva 1773 (MBM). Morretes, 8.X.2005, f1., M.G. Caxambu 874 (MBM). Paranaguá, 10.X.2013, fl., M.L. Brotto 1342 (UPCB); Ilha do Mel, 07.II.1986, fl., S.M. Silva 1053 (UPCB); Pontal do Sul, fl., J.T. Motta 2306 (MBM). Piraquara, 13.X.2001, fl., P.H. Labiak 1948 (UPCB). Pontal do Paraná, Ilha do Mel, 25.IX.2004, fl., D.C. Maia (UPCB 50249). Quatro Barras, 27.III.1990, fl., O.S. Ribas 300 (MBM). São José dos Pinhais, 12.VII.1988, fl., F. Straube 51 (MBM).

Espécie endêmica do Brasil, ocorre nos estados do Rio Grande do Sul, Santa Catarina, Paraná, São Paulo, Rio de Janeiro, Espírito Santo e Bahia (BFG 2015). No Paraná ocorre em Floresta Ombrófila Densa e Mista. É uma epífita abundante em vegetação litorânea e em florestas úmidas. Floresce e frutifica o ano todo, com menor intensidade em junho e julho. Espécie facilmente reconhecida pelas folhas glabras, brilhantes e elípticas e pela corola branca com a garganta manchada, é distinta de C. cordifolia pela base das folhas, que é cordiforme nessa espécie.

\section{Gloxinia L'Hér., Hort. Kew. 2: 331. 1789.}

Ervas perenes, terrestres. Caule perene subterrâneo desenvolvido em rizomas escamosos, caule aéreo anual sem raízes adventícias, pouco ramificado. Folhas opostas, isófilas. Inflorescências racemosas, com uma flor por axila, bracteosa, folhas gradualmente tornando se brácteas em direção ao ápice da inflorescência; bractéolas ausentes; corola pouco zigomórfica, campanulada; estames 4, inclusos, estaminódio ausente, conectivo pouco desenvolvido, anteras rimosas; nectário 1 , anelar a anelar lobado ou ausente; ovário ínfero; estigma estomatomórfico. Fruto do tipo cápsula seca, sementes com funículo delgado.

Gênero com quatro espécies, ocorrendo na América Central e do Sul (Araújo 2007; Weber 2004). No Brasil ocorrem três espécies (BFG 2015) e no Paraná somente Gloxinia perennis.

3.1. Gloxinia perennis (L.) Fritsch, Nat. Pflanzenfam. 4(3b): 174. $1874 . \quad$ Figs. 2g; 4a-d Ervas $25-55 \mathrm{~cm}$ alt. Caule cilíndrico, glabro, verde com manchas vináceas. Folhas com pecíolo 1,6-9,4 cm compr., lâmina 6,7-17,1 × 7,5-13,2 cm, ovada a orbicular, papirácea, glabra ou pubescente, ápice agudo a obtuso, base cordada, margem serreada, 5-8 nervuras secundárias. Inflorescência racemosa, brácteas $1,2-2,2 \times 0,8-1,4 \mathrm{~cm}$ patentes a reflexas, ovadas a elípticas; flores com pedicelo $1,1-2,1 \mathrm{~cm}$, ereto, verde, glabro; sépalas 1,3-1,6 $\times 0,5-0,7 \mathrm{~cm}$, patentes a reflexas, elípticas a obovadas, papiráceas, verdes, glabras; corola $2,8-3,8 \times 2,2-2,9 \mathrm{~cm}$, pubescente, lilás a rosada, fauce glabra com uma grande mancha roxa próximo à base (osmóforo), lobos 0,9-1,2 × 1,1-1,7 cm, patentes, desiguais, lilás a rosado; estames $1,8-2 \mathrm{~cm}$ compr., branco-amarelados; ovário ca. 1,1 $\times 0,6 \mathrm{~cm}$, cônico, glabro a pubescente, verde, estilete $1-1,3 \mathrm{~cm}$ compr., branco azulado, estigma estomatomórfico. Cápsula, marrom esverdeada 1,5-2,3 × 4,3-5,1 cm cônica, glabra a pubescente, verde.

Material examinado: Antonina, 10.IV.2003, fl. e fr., M. Borgo 2307 (MBM). Jundiaí do Sul, 21.III.2007, fl., J.M. Silva 5649 (MBM).

Material adicional: BRASIL. BAHIA: Salto Pancada Grande, 22.III.2005, fl., G. Hatschbach 79300 (MBM). MATO GROSSO: Rio Jacobina, 5.V.1995, fr., $G$. Hatschbach 62339 (MBM).

Espécie amplamente distribuída na América Central e do Sul (Araujo 2007). No Brasil é encontrada no Paraná, Minas Gerais, Mato Grosso do Sul, Mato Grosso, Goiás, Bahia, Ceará, Pernambuco, Alagoas, Pará, Amazonas e Acre (BFG 2015). No Paraná ocorre em Floresta Ombrófila Densa, mas é provável que as plantas coletadas no estado tenham escapado ao cultivo, já que não há outras coletas provenientes de 


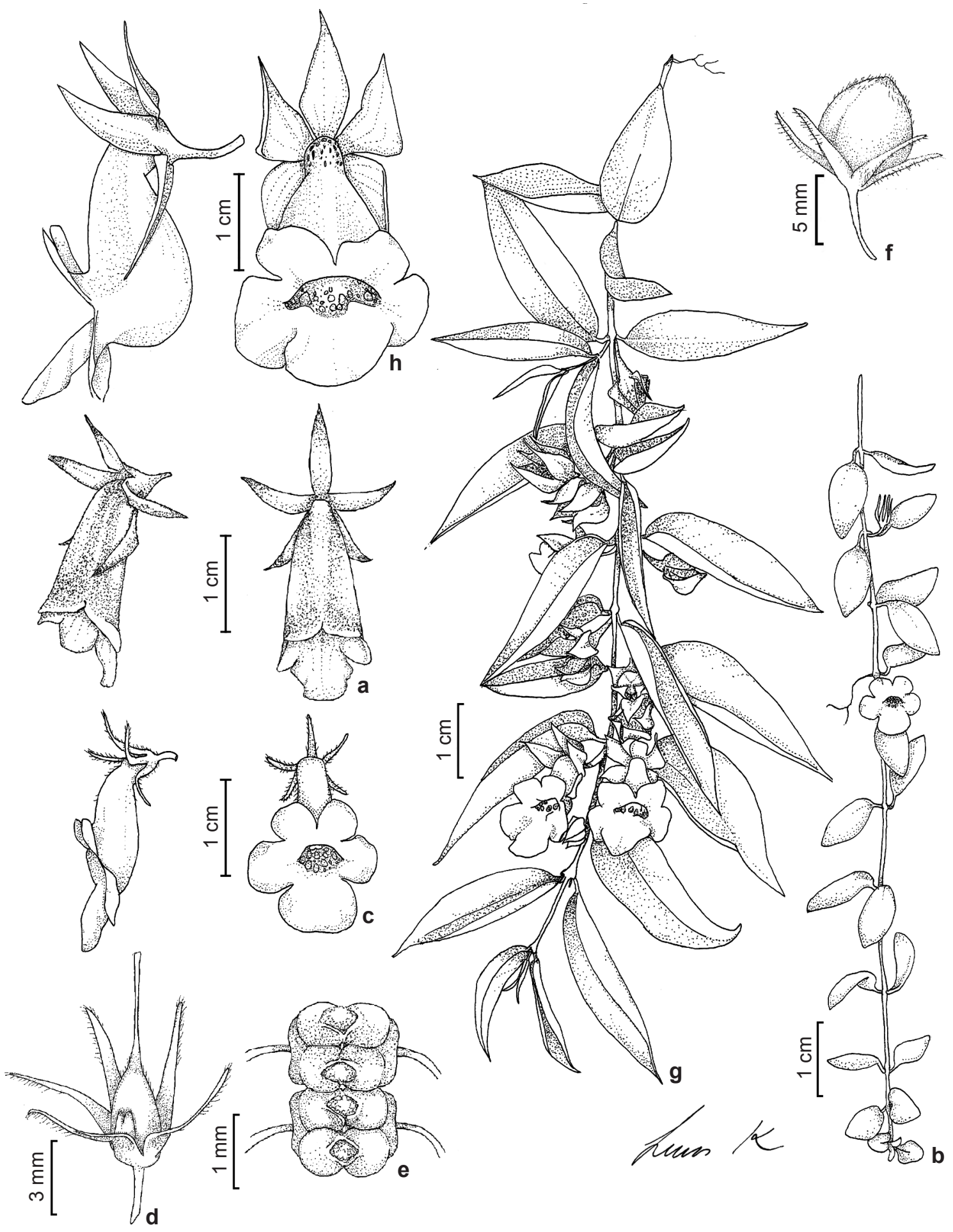

Figura 3 - a. Codonanthe cordifolia - a. vista frontal e lateral das flores. b-f. Codonanthe devosiana - b. hábito; c. vista frontal e lateral das flores; d. flor com a corola removida, mostrando ovário e nectários; e. anteras; f. fruto. g-h. Codonanthe gracilis - g. hábito; h. vista frontal e lateral das flores. (a. Motta 4400; b-f. Smidt 1076; g-h Hinoshita 60). Figure 3 - a. Codonanthe cordifolia - a. front and side views of the flowers. b-f. Codonanthe devosiana - b. habit; c. front and side views of the flowers; d. flower without the corolla, showing the ovary and nectaries; e. anthers; f. fruit. g-h. Codonanthe gracilis - g. habit; h. front and side views of the flowers. (a. Motta 4400; b-f. Smidt 1076; g-h. Hinoshita 60). 


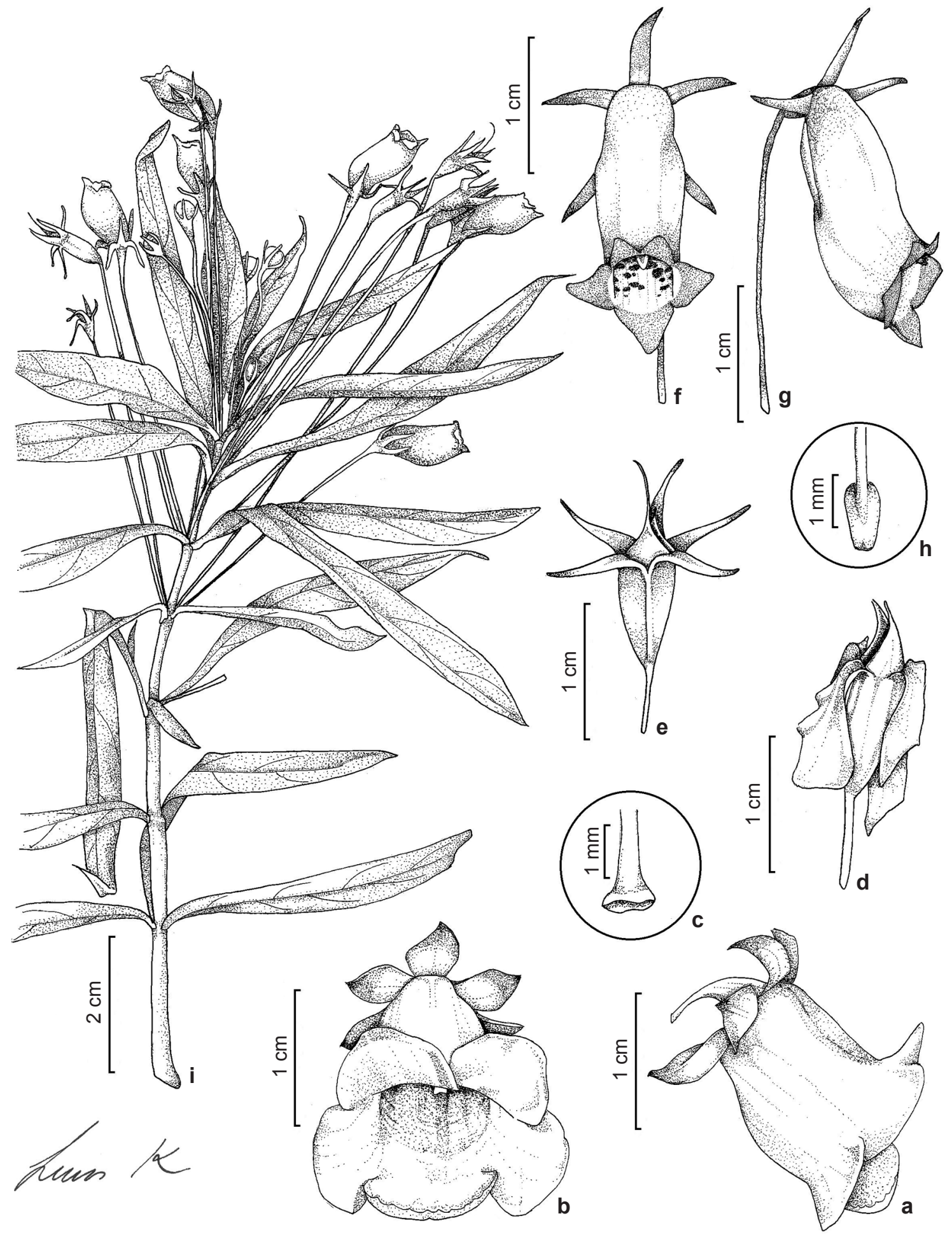

Figura 4 -a-d. Gloxinia perennis - a. vista lateral das flores; b. vista frontal das flores; c. estigma; d. fruto. e-i. Seemannia sylvatica -e. fruto; f. vista frontal das flores; g. vista lateral das flores; h. estigma; i. hábito. (a-d. Hatschbach 79300; e-i. Dunaisky Jr. 603). Figure 4 - a-d. Gloxinia perennis - a. side view of the flowers; b. front view of the flowers; c. stigma; d. fruit. e-i. Seemannia sylvatica - e. fruit; f. frontal view of the flowers; g. side view of the flowers; h. stigma; i. habit. (a-d. Hatschbach 79300; e-i. Dunaisky Jr 603). 
estados vizinhos. Floresce e frutifica em março e abril. Gloxinia perennis é reconhecida pelas flores azuladas e grandes, com um grande osmóforo roxo na base da fauce. É semelhante a G. alterniflora A.O. Araujo \& Chautems, mas essa espécie tem flores em disposição alterna e cálice lanoso. Muito cultivada como ornamental devido à beleza das flores.

4. Napeanthus Gardn., London J. Bot. 2: 13. 1843. Ervas perenes, terrestres. Caule ausente ou curto e prostrado sobre o substrato, sem raízes adventícias. Folhas em roseta, isófilas, membranáceas. Inflorescências axilares, cimosas, flores numerosas; brácteas presentes; bractéolas presentes; corola tubuloso-campanulada actinomórfica ou pouco zigomórfica; estames 4 ou 5, inclusos, quando 4 com estaminódio presente, anteras rimosas; nectário ausente; ovário súpero, estigma bilobado. Fruto do tipo cápsula seca, sementes com funículo delgado.

Gênero neotropical com cerca de 20 espécies (Leeuwenberg 1958; Weber 2004). No Brasil ocorrem somente quatro espécies (BFG 2015) sendo duas ocorrentes no estado do Paraná.

\subsection{Napeanthus primulifolius (Raddi) Sandwith,} Webbia 12: 332. 1956.

Figs. 1d-h

Ervas $12-22 \mathrm{~cm}$ alt. Caule cilíndrico, glabro. Folhas sésseis, lâmina 6,6-18 × 1,9-5,5 cm, oblanceolada a espatulada, glabra na face adaxial e pilosa principalmente sobre as nervuras na face abaxial, ápice obtuso a acuminado, base auriculada a atenuada, margem serreada, 6-9 nervuras secundárias. Cimeiras fasciculadas, com 2-5 flores; pedúnculo 3,8-15,5 cm; brácteas 1,0-1,2 $\times$ $0,3-0,4 \mathrm{~cm}$ lineares a estreito-lanceoladas; pedicelo 1,6-3,6 cm, ereto, verde, glabro a glabrescente; sépalas $0,7-1,4 \times 0,3-0,6 \mathrm{~cm}$, eretas, elípticas a lanceoladas, membranáceas, verdes, glabrescentes; corola 1,0-1,1 × 4,9-6,1 cm, glabra, azulada; lobos 2-3 $\times 3-4 \mathrm{~mm}$, patentes, iguais, emarginados, mais azulados que o restante da corola, abertura da fauce reduzida a ca. $1 \mathrm{~mm}$ diam.; estames 4 , com um pequeno estaminódio, ca. $4 \mathrm{~mm}$ compr., branco-amarelados; ovário ca. $3 \times 1 \mathrm{~mm}$, ovóide, glabro, verde claro, estilete ca. $4 \mathrm{~mm}$ compr., branco, estigma bilobado. Cápsula ca. $3 \times 2 \mathrm{~mm}$ ovóide, glabra, verde.

Material selecionado: Guaraqueçaba, 13.I.2001, fl., A.C. Cervi 8123 (UPCB); 9.I.2000, fl., A.L.S. Gatti 330 (UPCB); 4.II.1971, fl., G. Hatschbach 26267 (MBM); 15.XI.1993, fl., G. Hatschbach 59775 (MBM);
12.II.2002, fl., J. Carneiro 1309 (MBM); 7.II.2016, fl., L.K.R. Hinoshita 52 (UPCB);.

Material adicional: BRASIL. SÃO PAULO: São Sebastião, 20.IV.2000, fl. e fr., J.P. Souza 3312 (MBM).

Espécie endêmica do Brasil, encontrada em Santa Catarina, Paraná, São Paulo, Rio de Janeiro e Espírito Santo (BFG 2015). No Paraná ocorre em Floresta Ombrófila Densa. Espécie rara, é frequentemente encontrada associada a córregos e riachos, em áreas úmidas e sombreadas de florestas litorâneas. Coletada com flores em janeiro e fevereiro e com frutos em abril. Napeanthus primulifolius é reconhecida pelas sépalas membranáceas e pétalas azuladas.

4.2. Napeanthus reitzii (L.B. Sm.) B.L. Burtt ex Leeuwenb., Acta Bot. Neerl. 7: 349. 1958.

Figs. 1i-k; $2 \mathrm{~h}$

Ervas $15-20 \mathrm{~cm}$ alt. Caule cilíndrico, glabro. Folhas sésseis, lâmina 7,8-18,5 × 1,8-4,5 $\mathrm{cm}$, oblanceolada a espatulada, glabra na face adaxial e pilosa principalmente sobre as nervuras na face abaxial, ápice obtuso a acuminado, base auriculada a atenuada, margem serreada, 5-8 nervuras secundárias. Inflorescência em cimeiras fasciculadas, com 1-3 flores, pedúnculo $2,7-9,2 \mathrm{~cm}$; brácteas $4 \times 6 \mathrm{~mm}$ lineares a estreitolanceoladas; flores com pedicelo $0,9-1,8 \mathrm{~cm}$, ereto, axilar, verde, pubérulo; sépalas $0,9-1,4 \times 0,5-0,7$ $\mathrm{cm}$ triangulares, pouco conadas na base, papiráceas, verdes, glabrescentes; corola 1,0-1,1 × 4,9-6,1 cm, glabra, azulada; lobos 9-10 × 3-5 mm, patentes, iguais, azulados, abertura da fauce ca. $1,5 \mathrm{~cm}$ diam.; estames 4, com um pequeno estaminódio, ca. $4 \mathrm{~mm}$ compr., branco-amarelados; ovário $3 \times$ $1 \mathrm{~mm}$, ovóide, glabro, verde claro, estilete ca. 4 mm compr., branco, estigma bilobado. Frutos não observados.

Material selecionado: Guaraqueçaba, 20.VIII. 2013, fl., J.M. Silva 8440 (MBM). Guaratuba, 27.II.1968, fl., G. Hatschbach 18648 (MBM). Morretes, 16.XII.1964, fl., G. Hatschbach 12037 (UPCB). Paranaguá, 12.III.1969, fl., G. Hatschbach 21251 (MBM). Piraquara, 20.I.1970, fl., G. Hatschbach 23880 (MBM).

Espécie endêmica do Brasil, encontrada em Santa Catarina e no Paraná (BFG 2015). No Paraná ocorre em Floresta Ombrófila Densa. Assim como $N$. primulifolius, é uma espécie rara, encontrada na região litorânea, frequentemente próxima a cursos d'água, em locais sombreados e úmidos. Coletada com flores de dezembro a agosto. A espécie é reconhecida pelas sépalas papiráceas e pétalas azuladas. 
5. Nematanthus Schrad., Gött. Gel. Anz.: 718. 1821.

Subarbustos perenes, epífitas ou rupícolas. Caule ereto, pendente ou rastejante, com raízes adventícias. Folhas opostas, iso ou anisófilas, carnosas (hipoderme desenvolvida em um tecido aquífero suculento). Inflorescências axilares, cimosas reduzidas a 1-4 flores; brácteas ausentes; bráctéolas presentes; flores ressupinadas ou não; corola urceolada ou tubular, raro campanulada; estames 4 , inclusos, estaminódio ausente, conectivo pouco desenvolvido, anteras rimosas; nectário único, dorsal, bilobado; ovário súpero, estigma estomatomórfico. Fruto do tipo cápsula carnosa; sementes com funículo carnoso.

Gênero endêmico do Brasil, ocorrendo na Mata Atlântica e Cerrado, com 31 espécies (BFG 2015; Chautems 1988; Chautems et al. 2005). No estado do Paraná ocorrem seis espécies.

5.1. Nematanthus australis Chautems, Candollea 39(1): 297. 1984.

Figs. 2i,j; 5a,b

Subarbustos epífitos ou rupícolas, 25-50 $\mathrm{cm}$ compr. Caule cilíndrico, glabrescente. Folhas isófilas; pecíolo 2,1-6,2 $\mathrm{mm}$ compr., cilíndrico, verde, pubérulo; lâmina $0,8-2,9 \times 0,6-1,4 \mathrm{~cm}$, elíptica ou ovada, crassa, verde nas duas faces, glabra ou pubérula sobre a nervura central em ambas as faces, ápice obtuso, base cuneada, margem inteira a serreada na metade superior, nervuras secundárias não aparentes. Flores não ressupinadas; pedicelo $0,6-1,5 \mathrm{~cm}$ compr., verde ou vináceo próximo à base, glabro; sépalas 0,9-1,4 × 0,3-0,7 cm, elípticas a ovadas, glabras, pubérulas próximo ao ápice, ápice agudo a obtuso, verdes, vermelhas ou verdes com o ápice avermelhado ou vináceo, não costadas; corola 1,2-2,2 cm compr., amarela, alaranjada ou avermelhada, horizontal em relação ao ramo, não sinuosa, gibosa, glabra, pilosa próximo aos lobos, tricomas glandulares no tubo próximo a abertura, abertura muito estreita; lobos patentes a eretos, com a mesma cor da corola; filetes $1,2-1,3 \mathrm{~cm}$ compr., branco amarelados; ovário 2,4-3 mm compr., glabro, estilete glabro, estigma capitado a estomatomórfico. Cápsula 8-12×7-8 mm, globoso, laranja a vináceo; placenta e funículos amarelados a alaranjados.

Material selecionado: Antonina, 29.III.2009, fl., R.R. Voltz 29 (UPCB). Campina Grande do Sul, 11.VII.1996, fl., Y.S. Kuniyoshi 5917 (UPCB). Guaratuba, 18.IX.2004, fl., H.M. Fernandes 43 (UPCB). Morretes, 23.IX.2000, fl., M.P. Petean 106 (UPCB). Piraquara, 31.VII.2004, fl., R. Varotto 22 (MBM, UPCB). Quatro Barras, 12.IV.1989, fl., E. Melo (UPCB 36293). São José dos Pinhais, fl. e fr., L.R. Landrum 2291 (MBM). Tijucas do Sul, 23.V.1990, fl., G. Hatschbach 54112 (MBM).

Espécie endêmica do Brasil, encontrada no Rio Grande do Sul, Santa Catarina e Paraná (BFG 2015). No Paraná ocorre em Floresta Ombrófila Densa e Floresta Ombrófila Mista. Nematanthus australis é frequente em altitudes elevadas, onde também ocorre como rupícola. Coletada com flores e frutos durante o ano todo, com maior frequência de março a julho. A espécie pode apresentar grande variação na cor do perianto, mesmo dentro de uma mesma população; a corola pode ser amarela, alaranjada, avermelhada ou estriada. Difere de $N$. gregarius D.L. Denham por não possuir manchas entre os lobos da corola e de $N$. wettsteinnii pela forma das sépalas, que são lineares nessa espécie.

\subsection{Nematanthus fissus (Vell) L.E.Skog, Baileya} 19: 150.1975.

Fig. 5c

Subarbustos epífitos, $20-55 \mathrm{~cm}$ compr. Caule cilíndrico ou tetrágono, viloso, glabrescente. Folhas anisófilas; pecíolo de 0,3-1,5 cm compr., verde a avermelhado, viloso; lâmina 2,6-9,5 × $1,1-3,4 \mathrm{~cm}$, elíptica ou obovada, crassa, verde nas duas faces, vilosa em ambas as faces, ápice acuminado, base cuneada, margem serreada, 2-4 nervuras secundárias, nervura central avermelhada. Flores 1-4 por axila, ressupinadas; pedicelo $1-2,2$ $\mathrm{cm}$ compr., verde ou avermelhado próximo à base, viloso; sépalas $1-1,8 \times 0,2-0,6 \mathrm{~cm}$, linearlanceoladas, vilosas, avermelhadas próximo ao ápice ou completamente vermelhas, ápice agudo, não costadas; corola 2,6-3,5 cm compr., alaranjada ou avermelhada, ereta em relação ao ramo, não sinuosa, estreitamente gibosa, giba voltada para o ápice, vilosa, tricomas maiores próximo aos lobos, abertura estreita; lobos patentes a eretos, alaranjados ou avermelhados; filetes $2,2-2,5 \mathrm{~cm}$ compr., branco amarelados; ovário 5-6 mm compr., pubescente; estilete pubescente próximo à base, estigma estomatomórfico. Cápsula 1,2-1,5 × 1-1,2 $\mathrm{cm}$, globoso, glabrescente, amarelo, placenta e funículos amarelados.

Material selecionado: Antonina 11.IX.1975, fl., G. Hatschbach 37046 (MBM). Caiobá, 4.IV.1953, fl., A. Mattos 4207 (UPCB). Guaratuba, 22.III.1989, fl., G. Hatschbach 29348 (MBM). Guaraqueçaba, 17.IV. 1993, fl., J. Prado 494 (MBM). Matinhos, 10.X.2002, fl., J. Sonehara 21 (MBM).

Espécie endêmica do Brasil, encontrada desde o Rio Grande do Sul até o Rio de Janeiro (Ferreira \& Chautems 2012). No Paraná ocorre em Floresta Ombrófila Densa e Floresta Ombrófila Mista. Nematanthus fissus é mais frequente em regiões litorâneas, em florestas úmidas, ou 
mesmo em vegetação de restinga. Coletada com flores durante o ano todo e com frutos de março a setembro. A espécie é facilmente reconhecida pelos caules e folhas vilosos e flores ressupinadas e alaranjadas ou avermelhadas.

5.3. Nematanthus jolyanus (Handro) Chautems, Candollea 39(1): 299. $1984 . \quad$ Fig. 2k; 5d

Subarbustos epífitos, 25-60 cm compr. Caule cilíndrico, estriado, pubescente quando jovem, glabrescente. Folhas anisófilas; pecíolo 0,8-3,5 cm compr., vináceo, pubescente; lâmina 3,4-13,4 $\times 2,9-5,8 \mathrm{~cm}$, elíptica ou raramente obovada, crassa, verde na face adaxial, avermelhada na face abaxial, pubérula sobre as nervuras somente na face abaxial, ápice acuminado, base aguda a cuneada, margem inteira, ciliada, 3-6 nervuras secundárias, avermelhadas. Flores, 1-5 por axila, ressupinadas; pedicelo 1,3-2,3 cm compr., vináceo a atropúrpureo, pubescente; sépalas 2-2,4 × 0,4-0,5 $\mathrm{cm}$, ovadas a oblongas, pubérulas próximo ao ápice e à base, ápice obtuso, margem com 2-3 dentes, vináceas a atropúrpureas, 5-costadas; corola 1,8-3,5 cm compr., amarela sem estrias, horizontal em relação ao ramo, sinuosa, gibosa, vilosa, abertura estreita, lobos patentes a eretos, alaranjados; estames 1,8-1,9 cm compr., brancos; ovário 4-5 mm compr., pubescente, estilete glabro, estigma estomatomórfico. Fruto não observado.

Material examinado: Guaraqueçaba, 23.IV.2002, fl., A. Cavassani 3 (MBM); 19.VII.1998, fl., A.L.S. Gatti 78 (UPCB); 20.III.1999, fl., A.L.S. Gatti 355 (MBM); 12.VI.2007, fl., C.B. Poliquesi 712 (MBM); 13.IV.2002, fl., G. Gatti 760 (MBM); 15.III.2000, fl., G. Hatschbach 70545 (MBM); 8.II.2016, fl., L.K.R. Hinoshita 53 (UPCB); 7.V.1994, fl., S.F. Athayde 62 (MBM).

Material adicional: BRASIL. São Paulo: Cananéia, 13.IX.1983, fl., F. de Barros 912 (SP); 12.IX.1990, fl., F. de Barros 1896 (SP). Iporanga, 18.VI.195, fl., A.B. Joly 1240 (SP).

Espécie endêmica do Brasil, encontrada no Paraná e São Paulo (BFG 2015). No Paraná ocorre em Floresta Ombrófila Densa, restrita à região de Guaraqueçaba, onde é pouco frequente. Coletada com flores de março a setembro, com maior frequência entre maio e julho. Nematanthus jolyanus é reconhecida pelas flores ressupinadas, cálice escuro, vináceo a atropúrpureo, e corola amarelada com lobos alaranjados.

5.4. Nematanthus maculatus (Fritsch) Wiehler, Selbyana 5(1):63. 1978. Fig. 5e

Subarbustos epífitos, 30-45 cm compr. Caule cilíndrico, liso, glabrescente. Folhas anisófilas; pecíolo 0,7-1,7 cm compr., verde escuro, pubérulo; lâmina 3,3-10,7 × 1,8-2,8 cm, elíptica ou ovada, crassa, verde na face superior e com grande mácula vinácea na face adaxial, cobrindo toda a superfície ou ausente, nervura central pubérula em ambas as faces, ápice atenuado, base cuneada, margem serreada, 3-5 nervuras secundárias, verdes ou vináceas. Flores 1 por axila, ressupinadas, pedicelo 8-13 mm compr., verde a avermelhado, pubescente a viloso; sépalas 8-10 × 2-3 mm, pubérulas a vilosas, ápice agudo, vermelhas, não costadas; corola 2-3 cm compr., rósea ou avermelhada, horizontal em relação ao ramo, parte tubulosa cilíndrica 1,3-1,8 cm compr., levemente sinuosa, gibosa, vilosa, abertura muito estreita, lobos patentes a eretos, em geral amarelados; estames 0,8-2,1 cm compr., branco amarelados; ovário 6-7 mm compr., pubescente, estilete glabro, estigma estomatomórfico, incluso. Cápsula $10 \times 8-9 \mathrm{~mm}$, ovóide, roxa, glabrescente, placenta e funículos amarelados.

Material analisado: Guaratuba, 26.II.1968, fl., G. Hatschbach 18638 (MBM); 5.XII.1970, fl., G. Hatschbach 23354 (MBM); 5.XII.1970, fl., G. Hatschbach 25759 (MBM). 25.VIII.1971, fl. e fr., G. Hatschbach 26938 (MBM).

Material adicional: BRASIL. SÃO PAULO: Mongagua, 4.IV.1983, fl., A. Chautems 73 (RB). Tapiraí, 31.III. 2013, fl., F.N. Cabral 913 (RB).

Espécie endêmica do Brasil, encontrada em Santa Catarina, Paraná e São Paulo (BFG 2015). No Paraná ocorre em Floresta Ombrófila Densa, na região litorânea. A espécie é rara, encontrada com maior frequência próxima a rios. Coletada com flores o ano todo e com frutos de maio a julho. Nematanthus maculatus é reconhecida pelas flores róseas com os lobos amarelos e pela mácula vinácea nas folhas, incomum no gênero.

5.5. Nematanthus tessmannii (Hoehne) Chautems, Candollea 39(1): 299. 1984 . Figs. 21,m; 5f,g

Subarbustos epífitos, 30-70 cm compr.; caule cilíndrico, pubescente a glabrescente. Folhas anisófilas, às vezes assimétricas; pecíolo 0,6-1,6 cm compr., verde escuro a castanho, pubérulo; lâmina 5-13 × 2-4 cm, elíptica ou ovada, crassa, verde nas duas faces, pubescente na face abaxial, ápice acuminado, base aguda, margem inteira, 4-6 nervuras secundárias, verdes. Flores 1-2 por axila, ressupinadas; pedicelo 0,9-2 cm compr., rosado, raramente esverdeado, pubérulo; sépalas $0,7-2 \times 0,5-0,9 \mathrm{~cm}$, pubérulas, ovadas, às vezes com um pequeno dente na margem, ápice agudo, verdes a rosadas, 5-costadas; corola 2,1-2,6 cm 
compr., amarela com estrias castanhas a vináceas, horizontal em relação ao ramo, parte tubulosa cilíndrica 0,6-1,7 cm compr., sinuosa, gibosa próximo ao ápice, pubescente, abertura muito estreita, lobos patentes, em geral castanhos ou amarelos com as mesmas estrias da corola; filetes 1,6-1,8 cm compr., branco a amarelados; ovário 0,4-0,7 cm compr., pubérulo, estilete glabro, estigma estomatomórfico. Cápsula ovóide, 0,9-1,1 $\times 0,6-0,8 \mathrm{~cm}$, viloso quando jovens, glabrescente, vermelho vináceo, placenta e funículos amarelados. Material selecionado: Campina Grande do Sul, 5.V.1963, fl., G. Hatschbach 10055 (MBM). Cerro Azul, 19.II.1981, fl., G. Hatschbach 43617 (MBM). Guaratuba, 17.VI.2008, fl., M.L. Brotto 153 (UPCB). Jaguariaíva, 13.VII.2005, fl., E. Barboza 1090 (MBM). Morretes, 29.V.2000, fl., A.L. Pasdiora 81 (UPCB). Paranaguá, 11.VII.1969, fl., G. Hatschbach 21249 (MBM). Piraquara, 6.VII.2002, fl., $R$. Goldenberg 574 (UPCB). Quatro Barras, 22.VII.1993, fl., O.S. Ribas 544 (MBM). Tunas do Paraná, 23.III.2001, fl., J.M. Silva 3355 (MBM).

Espécie endêmica do Brasil, encontrada no Rio Grande do Sul, Santa Catarina, Paraná e São Paulo (BFG 2015). No Paraná ocorre em Floresta Ombrófila Densa e Mista, e raramente em Floresta Estacional. Nematanthus tessmannii é mais frequente em florestas úmidas e em altitudes mais elevadas. Coletada com flores o ano todo, principalmente de março a julho, com frutos de julho a setembro. A espécie é reconhecida pela flor ressupinada, como em $N$. fissus, mas com cálice escuro e corola amarela estriada, característica incomum em Nematanthus. Difere de $N$. striatus (Handro) Chautems por essa espécie possuir cálice vinoso e denteado.

5.6. Nematanthus wettsteinnii (Fritsch) H. E. Moore, Baileya 19: 38. $1973 . \quad$ Figs. 2i; 5h-k

Subarbustos epífitos, raramente rupícolas, 30-60 cm de compr. Caule cilíndrico, liso ou pouco estriado, pubérulo quando jovem, glabrescente. Folhas isófilas, simétricas; pecíolo 2-4 mm compr., verde, pubérulos; lâmina $1,1-2,5 \times 0,8-1,1 \mathrm{~cm}$, elíptica ou ovada, crassa, verde nas duas faces, nervura central e próximo ao ápice em ambas as faces pubérulos, ápice obtuso, base cuneada, margem inteira, nervuras secundárias não aparentes. Flores 1 por axila, não ressupinadas; pedicelo $0,5-1 \mathrm{~cm}$ compr., verde, pubérulo; sépalas $0,5-1,3 \times 0,1-0,2$ cm compr., lineares, pubérulas, ápice subulado, verdes, não costadas; corola 1,6-2,1 cm, alaranjada ou avermelhada, horizontal em relação ao ramo, parte tubulosa cilíndrica $0,4-0,7 \mathrm{~cm}$ compr., não sinuosa, gibosa, pubescente, tricomas glandulares na fauce próximo à abertura, abertura da fauce muito estreita, lobos 1,5-2 × 1,2-2 mm eretos, amarelados; filetes 1,2-1,3 cm compr., branco amarelados; ovário 4-5 mm compr., pubérulo, estilete glabro, estigma estomatomórfico. Cápsula 6-9 × 5-8 mm, ovóide, glabrescente, alaranjado, placenta e funículos amarelados.

Material selecionado: Adrianópolis, 28.VII.1999, fl., J.M. Cruz 138(MBM). Antonina, 17.V.1965, fl., G. Hatschbach 12807 (MBM). Curitiba, 14.VII. 2011, fl., B.K. Canestraro 146 (MBM). Guaratuba, 26.II.1968, fl., G. Hatschbach 18637 (MBM). Morretes, 8.VII. 2011, fl., E.D. Lozano 610 (MBM). Pinhais, 24.VIII.1999, fl., M.P. Petean 69(UPCB). Tunas do Paraná, 23.III.2001, fl., J.M. Silva 3364 (MBM). Quatro Barras, 28.VI.1982, fl., P.I. Oliveira 557 (MBM). Serra da Baitaca, 31.V.1996, fl., A.L. Schutz 46 (UPCB).

Espécie endêmica do Brasil, encontrada no Paraná e em São Paulo (BFG 2015). No Paraná ocorre em Floresta Ombrófila Densa e Floresta Ombrófila Mista. É uma espécie abundante, principalmente como epífita. Coletada com flores de janeiro a setembro, mais frequentes de março a julho, com frutos de março a setembro. A espécie é reconhecida pelas sépalas lineares, corola avermelhada e bruscamente gibosa. Difere de $N$. australis principalmente pelas sépalas lineares ( $v s$. elípticas a ovadas em $N$. australis). Frequentemente cultivada como ornamental e conhecida pelo nome de peixinho ou columéia-peixinho.

\section{Seemannia Regel, Gartenflora 4: 183. 1855.}

Ervas perenes terrestres. Caule perene subterrâneo desenvolvido em rizomas escamosos, caule anual cilíndrico, sem raízes adventícias. Folhas opostas ou 3-verticiladas, isófilas, papiráceas. Inflorescências racemosas ou axilares, uma ou duas flores por axila; foliosas; bractéolas ausentes; corola tubular; lobos eretos, triangulares; estames 4, inclusos, estaminódio ausente, conectivo pouco desenvolvido, anteras rimosas; nectário 1, anelar; ovário ínfero, estigma clavado. Fruto do tipo cápsula seca, sementes com funículo delgado.

Gênero com quatro espécies, encontrado em quase toda a América do Sul, ao longo dos Andes e na periferia da Bacia Amazônica (Araujo 2007). No Brasil ocorrem duas espécies (BFG 2015), e no Paraná somente Seemannia sylvatica.

\subsection{Seemannia sylvatica (Kunth.) Hanst., Linnaea} 29: 540. 1859.

Figs. 2n; 4e-i

Ervas 15-40 cm compr., caule cilíndrico, verde a verde avermelhado, pubescente. Folhas não anisófilas, sésseis; lâmina 3-11,9 × 0,9-1,5 cm, elíptica-alongada, pouco suculenta, verde em ambas as faces e às vezes avermelhadas na base, pubescente 


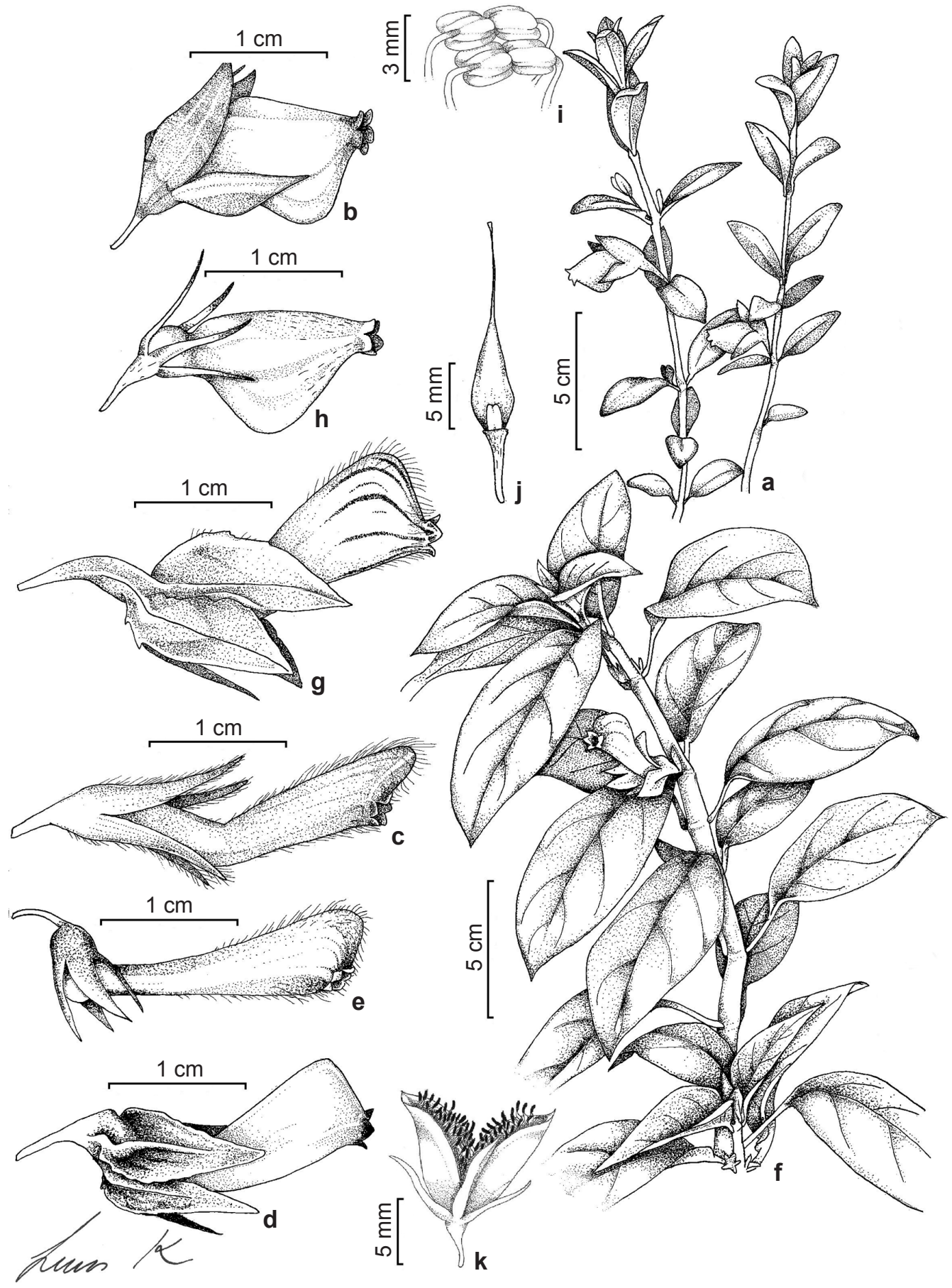

Figura 5 - a-b. Nematanthus australis - a. hábito; b. vista lateral das flores. c. N. fissus - vista lateral das flores. d. N. jolyanus - vista lateral das flores. e. N. maculatus - vista lateral das flores. f-g. N. tessmannii-f. hábito; g. vista lateral das flores. h-k. N. wettsteinnii - h. vista lateral das flores; i. anteras; j. flor com a corola removida, mostrando ovário, estilete e nectários; k. fruto. (a-b. Hinoshita 37; c. Hatschbach 29368; d. Hinoshita 54; e. Hatschbach 26938; f-g. Hinoshita 33; h-k. Hinoshita 38).

Figure 5 - a-b. Nematanthus australis - a. habit; b. side view of the flowers. c. $N$. fissus - side view of the flowers. d. N. jolyanus - side view of the flowers. e. N.maculatus - side view of the flowers. f-g. N. tessmannii - f. habit; g. side view of the flowers. h-k. N. wettsteinnii - h. side view of the flowers; i. anthers; j. flowers without the corolla, showing the ovary, style and nectaries; k. fruit. (a-b. Hinoshita 37; c. Hatschbach 29368; d. Hinoshita 54; e. Hatschbach 26938; f-g. Hinoshita 33; h-k. Hinoshita 38). 
em ambas as faces, ápice agudo, base atenuada, margem inteira, às vezes avermelhada, 3-5 nervuras secundárias. Flores 1-2 em cada axila, pedicelo 5,1-15,2 cm compr., cilíndrico, verde a verde avermelhado, pubescente; sépalas $0,5-1 \times 0,1-0,3$ $\mathrm{cm}$, pouco unidas próximo a base, lineares, eretas, lobos do cálice 4-8 cm compr., margem inteira, crassos, verde a verde avermelhados; corola 1,1-2,1 $\times 0,3-0,9 \mathrm{~cm}$, tubular, alongada, inflada e gibosa próximo à abertura, vermelha externamente, amarela internamente, com pontuações avermelhadas, pubescente com tricomas glandulares próximo à abertura da fauce; lobos 2-4 × 2-3 mm, triangulares, eretos, iguais entre si; estames 4, 0,9-1,8 cm compr., filete branco-amarelado; ovário 3-6 × 3-4 mm, cônico, pubescente, verde avermelhado, estilete 0,4-1,6 cm compr., amarelado, pubescente, estigma clavado. Cápsula 1,4-1,6 × 0,4-0,5 cm, cônica, pubescente, marrom.

Material analisado: Curitiba, 11.V.1998, fl. e fr., $A$. Dunaiski Jr. 603 (UPCB); 16.VI.2007, fl., R.M. Moura (MBM 340955).

Material adicional: BRASIL. MATO GROSSO DO SUL: Aquiadauana, 12.VIII.1970, fl., G. Hatschbach 24588 (UPCB). Bonito, 25.VIII.1991, fl. e fr., A.C. Cervi 3385 (UPCB).

Espécie ocorrente no Equador, Peru, Bolívia, Paraguai e Brasil (Araujo 2007). No Brasil é encontrada no Paraná, São Paulo, Minas Gerais, Mato Grosso do Sul, Mato Grosso, e Goiás (BFG 2015). As coletas no estado são provavelmente originadas plantas que escaparam ao cultivo, ocorrendo em áreas alteradas urbanas. Coletada com flores e frutos o ano todo. Seemania sylvatica é reconhecida pela corola vermelha com o interior do tubo amarelo e manchado.

\section{Agradecimentos}

À CAPES, a bolsa de Mestrado concedida ao primeiro autor, e ao CNPQ, a bolsa de Produtividade em Pesquisa concedida ao terceiro autor; aos curadores dos herbários EFC, GUA, HRJ, MBM, R, RB, SP, UPCB o envio de imagens e consulta aos acervos; a Gabriel Emiliano Ferreira e a Paulo Schwirkowski as fotografias. Agradecemos com destaque ao Dr. Alain Chautems, o auxílio na identificação das espécies e a correção e sugestões ao manuscrito.

\section{Referências}

Araujo A(2007) Estudos taxonômicos em Gloxinia L'Hér. sensu lato (Gesneriaceae). Tese de Doutorado. Universidade de São Paulo, São Paulo. 175p.
Araujo AO, Souza VC \& Chautems A (2005) Gesneriaceae of Cadeia do Espinhaço in Minas Gerais, Brazil. Brazilian Journal of Botany 28: 109-135.

BFG - The Brazil Flora Group (2015) Growing knowledge: an overview of seed plant diversity in Brazil. Rodriguésia 66: 1085-1113.

Burtt BL \& Wiehler H (1995) Classification of the family Gesneriaceae. Gesneriana 1: 1-4.

Chautems A (1988) Révision taxonomique et possibilités d'hybridations de Nematanthus Schrader (Gesneriaceae), genre endémique de la forêt côtière brésilienne. Dissertationes botanicae 112: 1-226.

Chautems A (1991) A família Gesneriaceae na região cacaueira de Bahia, Brasil. Revista Brasileira de Botânica 14: 51-59.

Chautems A \& Matsuoka CYK (2003) Gesneriaceae. In: Wanderley MGL, Shepherd GJ, Giulietti AM \& Melhem TS (ed.) Flora fanerogâmica do estado São Paulo. Vol. 3, pp 75-103.

Chautems A, Lopes TCC, Peixoto M \& Rossini J (2005) Five new species of Nematanthus Schrad. (Gesneriaceae) from eastern Brazil with a revised key to the genus. Selbyana 25: 210-224.

Chautems A, Lopes TCC, Peixoto M \& Rossini J (2010) Taxonomic revision of Sinningia Nees (Gesneriaceae) IV: six new species from Brazil and a long overlooked taxon. Candollea 65: 241-266.

Chautems A \& Perret M (2013) Redefinition of the neotropical genera Codonanthe (Mart.) Hanst. and Codonanthopsis Mansf. (Gesneriaceae). Selbyana 31: 143-156.

Ferreira GE \& Chautems A (2012) Nova ocorrência de Nematanthus fissus (Vell.) L.E. Skog (Gesneriaceae, Episceae) para o Rio Grande do Sul. Revista Brasileira de Biociências 10: 244-247.

Ferreira GE, Costa LG, Araujo AO, Hopkins MG \& Chautems A (2015) Three new species of Besleria (Gesneriaceae) from the southeastern of Brazilian Atlantic Rainforest. Phytotaxa 263: 270-278.

Hinoshita LKR \& Goldenberg R (2014) Gesneriaceae. In: Kaehler M, Goldenberg R, Evangelista PHK, Ribas OS, Vieira AOS \& Hatschbach GG (eds.) Plantas vasculares do Paraná. Universidade Federal do Paraná, Curitiba. Pp. 121-122

IAPAR - Instituto Agronômico do Estado do Paraná (1978) Cartas climáticas básicas do estado do Paraná. IAPAR, Londrina. 49p.

Kaehler M, Goldenberg R, Evangelista PHK, Ribas OS, Vieira AOS \& Hatschbach GG (2014) Plantas vasculares do Paraná. Universidade Federal do Paraná, Curitiba. 190p.

Labiak PH (2014) Aspectos fitogeográficos do Paraná. In: Kaehler M, Goldenberg R, Evangelista PHK, Ribas OS, Vieira AOS \& Hatschbach GG (eds.) Plantas vasculares do Paraná. Universidade Federal do Paraná, Curitiba. Pp. 7-22. 
Leeuwenberg AJM (1958) The Gesneriaceae of Guiana a critical revison with notes on species from adjacent regions. Acta Botanica Neerlandica 7: 291-435.

Lopes TCC, Andreata RHP \& Chautems A (2008) Distribuição e conservação do gênero Besleria L.(Gesneriaceae) no Brasil: dados preliminares. Revista Brasileira de Biociências 5: 876.

Lorenzi H \& Souza H (2008) Plantas ornamentais no Brasil: Arbustivas, herbáceas e trepadeiras $4^{\mathrm{a}}$ ed. Instituto Plantarum, São Paulo. 1088p.

Maack R (1981) Geografia física do estado do Paraná. 2a ed. José Olympio, Rio de Janeiro / Sec. da Cultura e do Esporte do Governo do Estado do Paraná, Curitiba. 526p.

Martinelli G \& Moraes MA(2013) Livro vermelho da flora do Brasil. Instituto de Pesquisas do Jardim Botânico do Rio de Janeiro, CNCFlora, Centro Nacional de Conservação da Flora, Rio de Janeiro. 1100p.

Perret M, Chautems A, Araujo AO \& Salamin N (2013) Temporal and spatial origin of Gesneriaceae in the New World inferred from plastid DNA sequences. Botanical Journal of the Linnean Society 171: 61-79.

Roderjan CV, Galvão F, Kuniyoshi YS \& Hatschbach GG (2002) As unidades fitogeográficas do estado do Paraná. Ciência \& Ambiente 24: 75-92.

Smith JF (1996) Tribal relationships within Gesneriaceae: a cladistic analysis of morphological data. Systematic Botany 21: 497-513.

Smith JF, Wolfram JC, Brown KD, Carrol CL \& Denton DS (1997) Tribal relationships in the Gesneriaceae: evidence from DNA sequences from the chloroplast ndhF. Annals of the Missouri Botanical Garden 84: 50-66.

Thiers B [continuously updated] Index Herbariorum: a global directory of public herbaria and associated staff. New York, Botanical Garden's Virtual Herbarium. Disponível em $<$ http://sweetgum.nybg. org/ih/>. Acesso em 20 maio 2015

Veloso HP, Oliveira-Filho LD, Vaz AMSF, Lima MPM, Marquete R \& Brazão JEM (1992) Manual técnico da vegetação brasileira, IBGE, Rio de Janeiro. 271p.

Weber A (2004a) Gesneriaceae and Scrophulariaceae: Robert Brown and now. Telopea 10: 543-569.

Weber A (2004b) Gesneriaceae. In: Kubitzki K \& Kadereit $\mathrm{J}$ The families and genera of vascular plants. Vol. 7. Dicotyledons. Lamiales (except Acanthaceae including Avicenniaceae). Springer, Berlin, Heidelberg. Pp. 63-158.

Weber A, Clark JL \& Möller M (2013) A new formal classification of Gesneriaceae. Selbyana 31: 68-94.

Wiehler H (1983) A synopsis of the neotropical Gesneriaceae. Selbyana 6: 1-219.

\begin{abstract}
Lista de coletores:
Aguiar OT 263 (1.1). Athayde SF 62 (5.3). Barboza E 1090 (5.5). Borgo M 263 (2.3), 472 (5.1), 2307 (3.1). Brotto ML 153 (5.5), 1342 (2.3), 1725 (2.2). Cabral FN 913 (5.4). Canestraro BK 146 (5.6). Carneiro J 1130 (2.2), 1309 (4.1). Cavassani A 3 (5.3). Caxambu MG 874 (2.3). Cervi AC 1973 (2.2),3385 (6.1), 7040 (2.2), 8123 (4.1). Chautems A 73 (5.4), 334 (5.6). Cordeiro J 1758 (2.3). Cruz JM 138 (5.6). Dala Rosa S 34. Davis PH 59909 (2.1). de Barros F 1896 (5.3). Dunaiski-Jr A 603 (6.1). Fernandes HM 43 (5.1). Gatti ALS 75(2.3), 78 (5.3), 140 (2.3), 330 (4.1), 355 (5.3). Geraldino HCL 125 (2.2). Goldenberg R 574 (5.5), 1269 (2.1). Hatschbach G 8318 (5.1), 9090 (2.2), 1055 (5.5), 12037 (4.2), 12807 (5.6), 13433 (4.2), 13428 (5.6), 13466 (2.3), 14062 (4.2), 14514 (2.2), 16345 (5.6), 18637 (5.6), 18638 (5.4), 18648 (4.2), 20637 (4.2), 21249 (5.5), 21251 (4.2), 24588 (6.1), 22871 (5.5), 23354 (5.4), 23880 (4.2), 25759 (5.4), 26267 (4.1), 26938 (5.4), 29348 (5.2), 29744 (5.5), 32987 (1.1), 37046 (5.2), 40344 (2.3), 43617 (5.5), 45267 (2.3), 54112 (5.1), 59775 (4.1), 62339 (3.1), 70545(5.3), 79300 (3.1). Hashimoto G s.n. (1.1, MBM 21780). Hinoshita LKR 33 (5.5), 38 (5.6), 52 (4.1), 53 (5.3). Joly AB 1240 (5.3). Kersten R 344 (2.3). Kirizawa M 1088 (1.1). Kozera C 910 (4.2), 938 (4.2), 1458 (2.2). Kummrow R 251 (5.2), 1942 (5.6), 2755 (2.2). Kuniyoshi YS 306 (2.3), 5851 (5.2), 5917 (5.1). Krieger PL 13357 (2.2). Labiak PH 1948 (2.3), 1918 (5.1). Landrum LR 2291 (5.1). Leitmann M 75 (2.1). Lima R 178 (1.1). Lindeman J 3201 (1.1). Lozano ED 610 (5.6). Maia DC s.n. (2.3, UPCB 50249). Mancinelli W 638 (2.1). Marinero F 194 (5.6). Martinelli G 7776 (2.1), 9066 (2.1), 9600 (2.1). Marzola ELC 155 (1.1). Matos A 4207 (5.2). Melo E s.n. (5.1, UPCB 36293). Meyer FS 765 (2.2). Moreira-Filho H s.n. (2.2, UPCB 9771). Motta JT 1687 (2.2), 2306 (2.3), 4400 (2.1). Moura RM s.n. (6.1, MBM 340955). Oliveira PI 557 (5.6). Pasdiora AL 81 (5.5). Petean MP s.n. (2.2, MBM 342150), 69 (5.6), 106 (5.1), 174 (5.5). Poliquesi CB 712 (5.3). Prado J 412 (2.3), 494 (5.2). Reginato M 388 (2.3), 414 (2.3). Reitz R 3398 (2.1). Ribas OS 300 (2.3), 544 (5.5) 804 (5.2), 964 (4.2). Santos A 38 (1.1). Schutz AL 46 (5.6). Silva JM 1053 (2.3), 1773 (2.3), 3135 (2.2), 3355 (5.5), 3364 (5.6), 8440 (4.2), 8465 (2.3), 5649 (3.1). Silva MG 24 (5.1). Smidt EC 1076 (2.2). Sonehara J 21 (5.2). Souza JP 3312 (4.1). Souza WS s.n. (2.2, MBM 112894). Stange EJ 32 (5.1). Straube F 51 (2.3). Sugiyama M 1074 (1.1). Varotto R 22 (5.1). Verdi M 4923 (2.2). Vieira FCS1175 (2.1). Voltz RR 29 (5.1).
\end{abstract}

Editora de área: Dra. Cássia Sakuragui Artigo recebido em 16/09/2016. Aceito para publicação em 21/03/2017. This is an open-access article distributed under the terms of the Creative Commons Attribution License. 